\title{
Papers
}

\section{Investigating the benefits of mutuality: A discussion of the demutualisation trend}

Received (in revised form) 18th March, 2002

\section{Richard Lewin}

obtained a first class BSc in Business Management from King's College, London. He is also a graduate of Fitzwilliam College, Cambridge, completing his Masters in Finance at the Economics and Politics Faculty, before preparing his doctoral thesis in Treasury and Asset Management at the Judge Institute of Management Studies. He is currently working as an Investment Strategist for Wiggins Group Plc.

\begin{abstract}
The financial services industry is probably unique in having a substantial mutual sector coexisting with, and competing against, joint stock firms. The last few years have encompassed a wholesale transformation of the UK building society and life assurance markets, as the majority of mutual providers have elected to change their corporate form, through the process of demutualisation. This powerful trend towards wholesale proprietary structures has occurred in the context of a general consolidation across the financial services community. In the middle of the last century, there were 18,000 friendly societies; today there are barely 200 , leaving many financial analysts questioning whether there remains any future for mutuality in the 21 st century. This paper discusses the recent dramatic changes at mutual life assurers, in the context of their being customer-oriented rather than investor-oriented businesses, and concludes with a review of the controversy surrounding events at Equitable Life (EL).
\end{abstract}

Keywords: demutualisation; Equitable Life; friendly societies; life assurance; mutuality

\section{Introduction}

In the UK, as in the USA, dozens of significant mutual banks and insurers have recently elected to become shareholder-owned institutions. ${ }^{1}$ This has raised some interesting problems for the residual mutual sector, particularly since ever more of them look set to change their status to that of proprietary

Richard Lewin The Judge Institute of Management Studies, 14a Trumpington Street, Cambridge, CB2 1AG, UK.

Tel: 01223 339700; Fax: 01223 339701; e-mail: ral1004@cus.cam. ac.uk businesses. Changing business circumstances have resulted in the need for a fresh look at the basic concept of operating as a mutual provider. At first sight, mutual life insurance companies have been operating under a number of potential disadvantages, with common factors including the adoption of the reasonable benefit expectation approach, a guarantee of bonuses to with-profits policyholders, and the establishment of guarantee funds from the 'orphan' assets of mutual insurers. ${ }^{2}$ Fabian $^{3}$ suggests that mutual companies may have outgrown their original purpose and have become an anachronism. Indeed, with the notable exception of Standard Life (SL), the remaining mutual societies have resorted to a tightening of the membership rules to dissuade carpet-baggers, ${ }^{4}$ rather than tackling the thornier issue of explicitly conveying to their present membership the unique 
benefits of retaining mutual status over the longer term.

In the UK, mutual institutions grew out of the friendly society movement of the 18th century, with the first mutual insurer, Equitable Life (EL), founded in 1762. The emergence of mutual assurance is linked with the Industrial Revolution and the need to provide for impoverished workers beyond the outmoded Elizabethan Poor Laws, as people congregated in the cities and lived in conditions of squalor and poverty. The historic principle of mutuality relates to this epoch, when sophisticated financial institutions, taken for granted today, did not exist. The only method of improving the quality of ordinary people's lives was through the development of cooperative and mutual societies, as formalised under the Friendly Societies Act 1819. Mutual institutions thus predated the welfare state and were formed to meet the needs of a burgeoning working class, comprised of mainly rural and immigrant workers. As a practical expression, this communitarian self-help movement allowed small regular individual contributions to be pooled for mutual collective benefit, obtaining the same economies of scope and scale necessary in providing collective insurance and banking products, to mitigate enduring social exclusion.

Initially funding was required for housing, consumer durables and emergency insurance provision, at a time when commercial banks were still exclusively commercial lenders. ${ }^{5}$ Building societies were formed as small temporary societies by worker cooperatives, pooling resources to build local houses and subsequently allocating them among members by drawing lots. Once all members were housed, these organisations were typically wound up, although some become permanent societies in an effort to promote wider home ownership, as exemplified by the Leeds Permanent Building Society. ${ }^{6}$ Surplus funds were then pooled, providing an opportunity for low-income families to earn interest on small deposits, with proceeds typically invested in residential mortgages and liquid government securities.

The traditional intermediation function of mutual societies was to promote thrift among the working classes and thereby provide access to low-cost home loans. This ethos has become obscured in the recent battle for customers, and only the very real threat of extinction has occasioned any renewed vigour in proclaiming the original mutuality message. Mutual societies continue to perform vital social functions, often serving on the boards of local community groups, as well as regularly making sizeable local charitable donations. Indeed, the mutual legacy of social benefaction, although quite substantial, risks only being missed by the present generation once such institutions ultimately cease to exist. ${ }^{7}$ With the conversion of most of the larger remaining mutual societies into proprietary companies, the bulk of the UK savings assets will have shifted away from their traditional providers into the mainstream UK financial sector. This change is occurring even as the traditional barriers between banks, building societies and insurance companies are disappearing. The spate of conversions is leading to a polarisation into two camps: the converters and the remaining mutuals.

\section{Mutual ownership and corporate governance}

A mutual institution is a specific corporate form owned by its membership, rather than shareholders, through their ongoing relationship with the organisation. Members have certain 
rights to vote, but largely restricted property rights. Principally these legal interests are not readily transferable, preventing any concentration in ownership. Members are, however, able to leave the organisation completely, by withdrawing their capital, whereas in listed companies the claim on the original equity subscription is merely transferable, and cannot be retracted. Mutual institutions owe their allegiance to their members, rather than potentially disinterested shareholders, obviating the paramount objective to generate a distributable profit. However, the cost savings, implicit in not having to pay a dividend, need to be carefully considered. This should not imply that mutuals ought to accept any lower rate of return on assets than their comparable shareholder-owned counterparts, unless they are trading on the ignorance of their membership. ${ }^{8}$ On the contrary, the capital in a business enterprise still incurs a direct cost that needs to be serviced, whether explicitly to shareholders, or implicitly to members.

One consequence of this ownership structure, however, is that mutual societies can afford to be a little more competitive on loan and deposit rates, with immediate benefits for their clients. The mutual form also allows them to make longer-term decisions with owner-independence, one of the most compelling arguments for the retention of their special status. Independence means not only local control, but moreover the ability to serve the specific interests of the local community. As the interests of stockholders and customers may differ, a proprietary company inevitably has to decide which path to follow, whereas the same question never arises in the case of mutual institutions, because shareholders and customers are synonymous.

Both corporate forms separate the ownership and control functions, typically delegating the latter responsibility to an appointed board of managers. The primary difference is in the level of corporate governance that each configuration affords. One controversial suggestion has been that mutual ownership can be regarded as fuzzy ownership, ${ }^{9}$ resulting in poor performance without the efficiency imposed through the discipline of serving dispassionate stockholders. Mutual insurers do not have to keep policyholders individually informed of annual general meetings or send them annual reports, ${ }^{10}$ although the convenience of the Internet medium as an information dissemination tool could prove a significant future weapon in combating such shortcomings and related corporate governance issues.

Mutual members are customers first and foremost, and absentee owners - at best - somewhat secondarily. A mutual concern exists purely to provide collective customer services, with any capital tied up in the intermediation process a pure function of it, rather than explicitly subscribed to by outside investors specifically to generate a return, as in proprietary organisations.

Conversely, PLCs are joint stock companies that issue shares directly to investors in order to raise funds, the shareholders becoming the ultimate owners of the firm, with contractual rights to any profit streams. The level of corporate governance directly implied in the mutual case, from an exceptionally dispersed ownership structure as a function of diffuse financial consumerism, is correspondingly very low. Academic discussion in this area by Cook, Deakin and Hughes ${ }^{11}$ has centred on the corporate governance issue in relation to mutual building societies, in direct response to the tide of conversions sweeping an otherwise sedate sector of the financial industry. 
Their ideas are discussed only in relation to building societies, but are readily applicable to the mutual life assurance sector as considered in this paper. Cook et al. argue that mutual societies are the victim of present circumstances and given the right conditions can still flourish, by enhancing returns to members over the longer term. They call for a revolution in the governance of mutuals, akin to the Hampel, Greenbury and Cadbury reforms witnessed in the proprietary sector. They propose 'electoral colleges', which would reward activist members and encourage greater supervision of management, or joint committees of directors and members to assist with communication. Their paper contends that mutuals have an important role to play in the diversity of the financial ecosystem, with additional important advantages over shareholder-owned businesses, primarily a potentially lower cost of capital versus PLCs, from the absence of external shareholders. Controversially however, Martin ${ }^{12}$ attributes this lower cost of capital advantage to a combination of loyalty, ignorance and inertia on the part of the membership. The principle of 'one member, one vote', the central tenet of the mutual movement, makes it extremely tough for members to exercise supervisory authority over management, facilitating the classic 'free rider' problem or more contemporarily speaking, the 'carpet-bagger' phenomenon. Green and Johnson $^{13}$ critique the mutual voting system, concluding that for mutuals, the mechanics of ownership meetings, notices and voting procedures are cumbersome and seldom used. Their survey offers some evidence for differences in the patterns of control exercised by legal owners of stock and mutual insurers. Shareholders are more aware of their right to vote, and exercise greater control by being more likely to attend annual meetings and vote for directors. This agency problem is exacerbated in the mutual case, as there are no large shareholders to put pressure on the board to improve levels of corporate governance.

A mutual membership is disparate and, despite the emergence of a few action groups in time of crisis, largely disorganised. Even for diligent members of a mutual society, the opportunity costs involved in monitoring management clearly outweigh any individual benefits, since the collective membership stands to benefit equally from any personal endeavours. Thus a truism of the proprietary market seems to be that only when ownership is concentrated in large institutional blocks or family holdings, where significant real risk capital is at stake, do these opportunity costs/benefits change to any marked degree. Moreover, the ownership and voting structure of mutuals is especially unwieldy at times of crisis, as demonstrated by more recent events at EL. Despite a collective mutual structure, the membership still found it difficult to agree on a ceiling to liabilities relating to contractual guarantees. Indeed the situation at EL is a very pertinent example, as policyholders with annuity rate guarantees initially appeared to have gained a windfall at the expense of other policyholders who did not enjoy such similar contractual advantages. This is the obverse of mutuality, as without outside shareholders to inject fresh equity capital, as required should things go wrong, there entails a zero-sum game, whereby any winnings necessarily have to come out of the losers' pockets.

\section{Mutuality: An endangered species}

Although mutual financial institutions now appear to be on the endangered species list, ${ }^{14}$ questions remain as to 
whether mutuality, as a concept, should be preserved - or suffer extinction as a result of a dispassionate 'Darwinian' economic fact. Unlike proprietary firms that provide a transparent return on capital, cooperatives' earnings belong exclusively to their members. These earnings are typically distributed in the form of patronage dividends, which are proportional to a patron's share of the cooperative's business. Any profits generated through the intermediation process, although attributable to members, are often exclusively returned by way of reduced transaction costs, or intermediation margins. Thus, the key to the mutual form resides in the efficiency generated where there is homogeneity of interests among customers, compared to the inefficiency where there is a divergence of such interests, a view supported by Mayers and Smith. ${ }^{15}$

Recent institutional changes, reflecting greater diversity in financial service provision, has arguably led to greater heterogeneity of interest among the mutual membership, facilitating the need for change in some cases. Competition among financial service providers has caused additional difficulties. Smaller not-for-profit societies struggle to sustain the marketing expense needed to ensure widespread awareness of their products, while retaining sufficient commission-based incentives to galvanise independent financial advisers (IFAs), to consider their offerings. In the absence of a direct salesforce, they have traditionally been reliant on referrals from mortgage and insurance brokers. This conduit of business is important to the mutual sector but more so for the assurance sub-sector as the prominent 'shop window' effect of the building society on the high street is missing.

The principle of mutuality is also at risk specifically in the life insurance sector, as consumers now increasingly demand to know exactly what is going on within the 'black-box' of with-profits funds, while simultaneously expressing unwillingness in sharing the risks as well as rewards with fellow policyholders, a point amply highlighted in the EL case. The sudden interest in demutualisation stems from an ability to place a saleable value on the goodwill of a mutual business, and not just simply on the underlying reserves. This, when combined with corporate and managerial ambition, may fuel customers' enthusiasm to vote for windfall payments.

According to Mackintosh, ${ }^{16}$ commenting on building societies, 'years of poor service, inefficient management and an interest-rate cartel ... meant members were only too willing to take the demutualisation shilling — windfalls of more that $£ 1,000$ were standard'. Speculators looking for gains have found carpet-bagging building societies a virtually one-way bet in recent years. The downside risk appeared de minimus - a modest sum of money tied into a poor interest rate - coupled with the upside of an uncertain windfall from eventual conversion, potentially only a few years ahead. The recent spate of demutualisations has forced the remaining mutuals to reassess their value to members, leading to the introduction of customer loyalty programmes and improved product pricing. However, while the short-term effect may be to increase the mutuals' market share, the unintended consequences are that it may inadvertently encourage further speculation. As many building societies raised the deposits to qualify for membership in reaction to these pressures, Nationwide recognised counter-intuitively that this discouraged the very membership the society was initially formed to promote, and responded instead by forming a charitable foundation to benefit from any windfalls 
attributable to new members. Mutual life assurance firms also face another set of problems relating to their ownership structure, as highlighted in the case of National Mutual by Bolger. ${ }^{17}$

Membership rights are only conferred on customers who have with-profits policies. This not only makes it difficult to raise capital to develop other parts of the business, but when the unit-linked side expands, a smaller percentage of customers consequently remain members. Operating a mutual society strictly in the interests of members, risks leaving it undercapitalised, with any commercial misjudgment, such as occurred at EL, resulting in the loss of independence. Conversely, running it in the interests of the society often means building up an excess capital cushion and thereby attracting carpet-baggers as a potential target for demutualisation.

Mutuality in life insurance remains an ongoing compromise between enhancing market share and maintaining a strong free-asset ratio; for if this dwindles below regulatory levels, insurers must temper their investment portfolios accordingly, and most likely compromise the level of fund performance by adopting a lower risk, bond-dominated, investment strategy. The other main pressure on mutual life insurers comes from diversification, with several assurers having successfully expanded away from their core businesses. A prime example is SL's bank, while Scottish Life's pension administration business became so successful that it threatened to be as valuable as the rest of the life operation. The society then had to consider how best to protect the interests of policyholders. Instead of selling a core function or demutualising, it opted to be acquired by Royal London, another mutual insurer, which itself is now considering how best to unlock value from the combined orphan estate. ${ }^{18}$
Smaller life insurers remain under genuine pressure to demutualise, in particular from escalating compliance costs as well as the cost of updating information technology.

The UK pensions and life insurance market is much more profitable than in other countries, according to Evans, ${ }^{19}$ but this advantage is being eroded with the introduction of low-cost stakeholder pensions with margins set at a maximum of 1 per cent, ${ }^{20}$ and the prevalence of commoditised offerings launched over the Internet. The recent move by many mutual financial institutions to become fully-fledged UK PLCs may be symptomatic of a continuing trend to address fundamental industry-related problems.

The principal distinction of mutual institutions is a lack of shareholders to answer to directly in respect of profit and dividend streams. Furthermore, the market for corporate control is obfuscated without the publicly available shareholder information, as required to conform to market listing criteria. The corollary to this is that mutuals are deprived of ready access to capital markets, which can be a potential handicap in times of financial stress. Increasingly, mutual societies recognise that there may be competitive disadvantages in not having access to primary markets for growth by acquisition, and the availability of their own equity to retain and motivate staff.

Restrictions on stock ownership may harm a company's performance, because restrictions prevent owners from choosing an optimal capital structure. Cole and Mehran ${ }^{21}$ examine the stock-price performance and ownership structure of a sample of US thrift institutions that converted from mutual to stock ownership. Their study found that after conversion and the expiration of ownership-structure restrictions, firm 
performance improved significantly, and the portions of the firm owned by managers and the firm's employee stock ownership plan also increased. Changes in performance were positively associated with changes in ownership by managers, but negatively associated with changes in ownership by employee share ownership schemes. Moreover, the overriding imperative to enhance returns to with-profits policyholders by increasing equity investment in pension schemes must be balanced by increased balance sheet depth to convince regulators of the prudence of any evolution in investment strategy.

\section{The benefits of mutuality}

Mutual societies exist to provide lower rates of interest on loans, ${ }^{22}$ longer-term security and convenience of supply to their membership, thus lessening financial exclusion, rather than simply providing returns by way of dividends and capital growth. In the case of mutual institutions, the provision of capital by savers to borrowers is an implicit function of the intermediation process and not part of organisational design, as evidenced by the fact that borrowers are still members, despite making no direct contribution to the organisational capital. The mutual structure therefore reflects more properly the long-term commitment of members who receive continuity in supply, and who have certain subsequent property rights.

Importantly customers transact with the mutual provider and receive particular benefits in direct proportion to their activities as both lenders and borrowers. This emphasis on reciprocity, commonality of interest, shared values and social purpose is advantageous in the context of specific long-term economic relationships such as mortgages, pensions and savings. The relatively low-risk, long-term nature of these investments may arguably lower the cost of capital for mutual providers. Gains from efficient performance can then be returned directly to mutual customers in the form of better services and rates, promoting a virtuous circle from the economies of scale across a plethora of financial services. Although mutual organisations are run for the collective benefit of policyholders rather than shareholders, with mutuality providing a moral and social good, ${ }^{23}$ commercial considerations retain importance. Introducing shareholders into the equation may actually lead to lower returns to policyholders, as shareholders have conflicting claims and priorities and subsequently demand a proportion of each year's investment gains, commensurate with the risk-adjusted cost of investment capital. However, efficiency in scope and scale due to improved market discipline through the primary and secondary markets may offset these deleterious effects to some extent.

There has also been a moral case made against wholesale conversion to PLC status, as proffered by Clarke. ${ }^{24}$ This is based on an argument that the accumulated property rights over the surplus capital of a mutual assurer have not all been contributed by present policyholders, but rather accrued over decades or even centuries. Thus the 'right' to an equity share in the reserves of the organisation is contestable, on grounds that it is the overriding duty of the directors (and thereby trustees of the inherited estate) to retain the reserves as a continuity legacy for the benefit of both current and prospective policyholders. This moral argument was the overriding principle, until changes in friendly society legislation, as typified by the Building Societies Act 1986 (as amended 1997), permitted 
demutualisation, with the residual fund appropriated by the present membership. However, the windfalls that accompany demutualisation were never intended to gratify exclusively the current transient membership. Mutual insurers sought to generate a level of surplus that would benefit not only current policyholders, but would further provide for the future capital needs of the company. The large majority of this surplus or 'orphan asset' was typically generated through premiums paid by persons who are no longer active policyholders of the company. A policyholder's relationship with the mutual insurer can be terminated for a variety of reasons, such as death, lapse or cancellation of the policy, and the former policyholder has no legal claim to a share of the company's surplus. Moreover, courts have consistently rejected efforts by

policyholders to seek distribution of the surplus of a mutual insurer, even upon its liquidation.

The Building Societies Association, in its response to the Banking Services Review in 1999, demonstrated that up to a third of the cost base of proprietary companies relates directly to the payment of dividends on equity capital. Of course, not all PLCs pay dividends, and some mutual societies have elected to pay bonuses directly to their membership as well. However, all redistributed profits, in the manner of reduced intermediation charges, are directly returned to ongoing customers as opposed to more transient shareholders. To the extent that the lower cost of capital argument can be sustained by empirical evidence, the preservation of a strong mutual financial services sector with the emphasis on putting customers first, should exert competitive pressure on alternative providers. ${ }^{25}$ The acute closeness and responsiveness to customers' needs are perhaps the most potent weapons in the struggle to retain a vibrant mutual sector. Naturally, demutualisation should only be economically justified if the average one-off windfall payment exceeds the overall intermediation benefits lost to a member, over a hypothetical membership timeframe. Regarding building societies, the Treasury Select Committee ninth report to the House of Commons in July 1999 suggested that the windfall payments to typical mortgage holders may be eroded in as little as four years. The weakness in this line of argument is that it does not apply to the band of carpet-baggers, investing the $\mathcal{K}_{100}$ minimum immediately prior to a conversion vote at building societies.

In itself though, this may highlight an undercurrent of short-termism in the demutualisation process, as mutuals clearly have the ability to formulate strategy in the best interest of their long-term customer base. This may include for example, the preservation of an extensive branch network covering rural communities, or in the case of insurers sustaining local rural salesforces over the longer term, without the inherent contradiction of near-term capital market discipline that might seek to disband such onerous service provision. The existence of mutual societies also provides plurality in corporate structures, which has been cited as an important means of retaining stability in the financial services sector. The lower risk and return profile of mutual institutions, as inferred by Genetay, ${ }^{26}$ may have allowed mutuals to survive economic crises better than their proprietary counterparts, as first proposed by Stahl. ${ }^{27}$ Thus diversity in the financial system, in terms of both ownership and capital structure, may contribute to a lowering of systemic risk in the financial system, by ensuring alternative responses to economic shocks. Social welfare considerations, such as financial 
exclusion, are also historic reasons for the formation and retention of mutual organisations, as well as the irreversibility of the demutualisation process. Lower intermediation rates suggest that capital remuneration is not the only thing that drives mutual businesses. Indeed, if friendly societies' members are willing to accept lower returns because they believe in the inherent values represented by mutuality, then mutual societies will continue to enjoy a massive advantage over joint stock companies, where return on capital is a paramount criterion. Valnek $^{28}$ examined the comparative performance of mutual building societies and retail banks in the UK. The results indicated that mutual building societies appear to have outperformed listed retail banks, suggesting that the benefits of mutual organisations may well outweigh those of joint stock organisations. These benefits stem from the merger of the owner and the depositor functions, and from their homogeneous clientele. Costs related to the conflicts between different classes of claimholders as well as conflicts within a single class of claimholders are thus avoided. Mutual societies' capital sources are, however, limited to retained profit and subordinated debt, although in most instances they could leverage their substantial reserves by issuing more subordinated debt, thereby obviating the imperative to become a listed vehicle on capital adequacy grounds alone. One alternative for capital raising has been to create a mutual holding company subsidiary, as often used in the USA and more exceptionally in Europe in Austria.

Often a culture of mutuality is important in describing how companies operate and who they are; downstream stock company alternatives allow them to retain the greatest degree of mutuality benefits while still accessing the capital markets. Although this has never been considered to any significant extent in the UK, a review of the controversy surrounding mutual holding structures in the USA can be found in Appendix 1. The principal drawback, at least in the $\mathrm{UK}$, is that mutuals are taxed more advantageously than proprietary companies, causing a disadvantage in tax terms from adopting such a structure, versus retaining exclusive mutual status. In addition, Barker, Dunham and Kelly ${ }^{29}$ consider that these activities may suggest weakness, adding credence to would-be predators in making a case to policyholders, via enhanced benefits and cash incentives, to surrender mutuality altogether. A case in point is the National Provident Institution (NPI), which adopted such a structure, as reviewed by Sanders, ${ }^{30}$ just before succumbing to a takeover by the insurer Australian Mutual Provident (AMP). On 19th May 2000, a 98.6 per cent majority of NPI members voted in favour of demutualisation, triggering windfalls of between $\AA^{3} 300$ and $\mathcal{E} 700 .{ }^{31} \mathrm{SL}$, Europe's largest mutual life insurer, saw off a conversion campaign last year, convincing just 54 per cent of its members to forfeit immediate cash windfalls and retain its mutual status. Based on repeated calls for conversion and the fragile margins in motion defeats, increasing insecurity pervades the mutual assurance industry. Nationwide, the building society, which itself narrowly beat a demutualisation campaign by 51 per cent in late 1998, voiced concerns that SL faced a more difficult task to remain mutual, as without a branch network it was not as close to its customers.

Mutuals still offer recognisable financial value, but public accountability is one way in which a mutual can add an extra dimension to its case. Losing touch with members, through an abrogation of public relations responsibilities is one of the central criticisms behind the current 
pressure for demutualisation.

Policyholders at Standard Life voiced considerable criticism of the board for the way in which it conducted its defence, and for its treatment of members in a haughty and high-handed manner.

Accusations of arrogance and a lack of transparency caused an unholy alliance of disparate members to unit against the company. Even if the genuine interests of policyholders are best served by a company remaining mutual, what SL has to do is go beyond this and improve its accountability to members, as well as being subject to a more open and critical examination of what it is doing on their behalf. However, in its defence, SL claimed its payouts on life and pension policies had outperformed the average for listed competitors by 9.3 per cent over the last 16 years. Moreover, SL shunned insurance industry practice in 1995 by severing the ties between charge and commission on its products. SL's narrow victory has come as slight relief to other beleaguered mutual assurers, although the numbers are still dwindling. Friends Provident, founded in 1832 by Quakers to provide life insurance, is the UK's seventh largest life assurer and erstwhile stalwart of the mutual vanguard ${ }^{32}$ and unique in taking over a public limited company while still a mutual. Quite what it discovered in taking over London and Manchester PLC in 1998 remains unknown, but perhaps because of that experience it demutualised by seeking a UK listing in July 2001. This

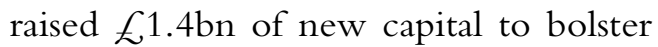
its financial strength in the stakeholder pensions market and pursue an aggressive equity-rich investment strategy.

Mutual companies return most of their profits to policyholders in the form of with-profit declarations. Thus the bonus and loyalty payment approach to rewarding members is more difficult for life assurers to pursue, versus building societies, because the nature of underlying business is longer-term and more complex. However Wesleyan Assurance, the Birmingham-based mutual founded by Wesley's Methodists in 1841 to serve the burgeoning working class, makes two annual bonus payments to its with-profits policyholders: the normal bonus declaration made by all with-profit funds, and a second 'mutuality' bonus or special 'dividend' to reinforce its mutual status credentials (see Guthrie). ${ }^{33}$

The Co-operative Wholesale Society (CWS), which owns the Co-operative Insurance Services (CIS), also believes mutuality has benefits beyond the mere financial. This communitarian movement was founded in 1844 in Rochdale as the Rochdale Equitable Pioneers Society. The Co-operative Group, formed out of the merger between the CWS and the Co-operative Retail Services (CRS) in 2000 , is the largest mutual retail organisation with over 1,100 stores employing more than 50,000 employees. The recent merger was prompted by the rumoured $\mathcal{E}_{1} 1.2 \mathrm{bn}$ bid by entrepreneur Andrew Regan to take control of CWS. Since then, the Co-operative Commission has orchestrated a master plan of the Co-op's long-term future and that of other mutual organisations within its remit, concluding that the movement can learn from PLCs, especially with regards to developing a performance culture, as discussed by Voyle. ${ }^{34}$ In 2000 , it issued its first 'social report', explaining what the organisation was doing for its members as well as the wider community.

The biggest friendly society ${ }^{35}$ remains the Liverpool Victoria Friendly Society (LV), formed in 1843 to provide for funeral expenses. Since then it has grown to become the UK's largest Friendly Society, with group assets over $\mathcal{C}^{7 \mathrm{bn}}$ and 
over $1 \mathrm{~m}$ members, providing a range of financial services including savings, investments and insurance. LV is a mutual self-help organisation, whose savings schemes and insurance plans are designed to be both affordable and accessible. A subsidiary, Liverpool Victoria Insurance Company Limited, is one of the largest direct insurers of cars, travel, buildings and home contents. Friendly societies have also played a part in insurance industry consolidation, with LV recently making three large acquisitions, Frizzell (an insurance broker), Landmark (a general insurer) and Equitable health insurance (a subsidiary of the Permanent). With the acquisition of the Frizzell Group in 1996, LV became the first and only friendly society to own a bank. Friendly societies have a separate set of regulations, some of which are out of step with the rest of the insurance sector - as exemplified by the limitation of what activities subsidiaries can undertake, such as outmoded restrictions on owning property. These restraints were addressed to some extent by the implementation of the Financial Services and Markets Act 2001, but the increasing cost of meeting regulatory demands remains disproportionately tough on friendly societies. However, one benefit under current UK tax law allows up to $£ 300$ a year to be invested tax-free in friendly societies.

Mutual companies can offer lower prices as a way of giving back profits and, while they may not target an explicit return-on-equity as a stock company, they still can pass on any difference in the form of lower premiums. Gilmore ${ }^{36}$ suggests that regularly returning surpluses to members rather than accumulating profits as reserves might mitigate the trend towards conversion in the mutual insurance sector. This must, however, be viewed in the appropriate context since windfall payments from mutual life insurers tend to be much greater than for building societies - the numbers of which are much reduced already — making them even more susceptible to membership revolts. For example, Scottish Widows policyholders were paid an average of over $£ 6,000$ each, following the $\mathcal{E}^{7}$.3bn takeover by Lloyds TSB at the end of 1999. The SL demutualisation proposal envisaged similar levels of payouts providing particularly strong incentives for policyholders nearing maturity. In the absence of clear-cut evidence of long-run dimunition of intermediation rates, as evident in the building society sector, the ability to ignore windfalls to all policyholders may remain an uphill struggle.

\section{The demutualisation debate}

Professional investors had been playing guessing games through opportunistic behaviour in depositing money with mutuals that might be considered likely candidates for a conversion, in the hope of a free-rider gain. Economists, however, are more interested in whether the overriding reason that mutuals are disappearing is due to an erosion of their historical economic advantage of a lower cost of capital. One important suggestion by Brown-Humes, ${ }^{37}$ when commenting upon demutualisation, contended that the cost efficiency enjoyed by mutuals rests on the marginal advantage they derive from not having to service an external capital base. The lower cost of capital is attributed to the fact that mutual societies do not remunerate their equity providers in any direct or overt way, unlike shareholders in proprietary organisations. Naivety or lack of financial sophistication on the part of the membership may explain this state of affairs, however implicitly mutuals offer 
more generous rates, so that they can continue to attract cheaper ongoing capital costs.

Stakeholder property rights have two essential aspects, the right to direct asset control and the right to receive surplus income from assets. Crucially, ownership rights in mutuals are not readily transferable in the same way as publicly limited companies. Investing members cannot sell their shares on the open market, preventing this most blatant expression of contempt for management, in the event of a continued decline in added value. The inability to bring management to account, as exercised by shareholders at AGMs and by the concentration of ownership among large institutional investors, reduces the opportunity and incentive to act as monitors of managerial behaviour. It should be noted, however, that although the general rule is one member one vote in mutual societies, some life insurance companies do allow voting rights to be proportioned in accordance with the size of premiums actually paid.

The shareholder structure in PLCs clearly separates residual claimants from decision-makers, facilitating the important diversification and spreading of risk, as noted by Fama and Jensen. ${ }^{38}$ This transferability allows capital markets to reflect the present value estimates of the firm, independently from assessing the characteristics of individual shareholders. The share price thus provides a volatile benchmark of the enterprise value, for management performance evaluation. While it is a popular view that a mutual culture provides the opportunity to manage a company for the long-term, financial analysts have not reported overwhelming evidence that mutual financial results are any better than those of stock companies focused on quarterly earnings.

Although the conversion pipeline appears to have dried up, the turmoil in the UK assurance system is unlikely to have ended. According to Warner, ${ }^{39}$ 'Some of the main reasons for demutualisation have included: the need for business diversification, access to alternative funding sources, a less stringent regulatory structure, and improved accountability to members'. Mutual insurers are said to be at a disadvantage in this environment because unlike stock insurance companies, which have the ability to use their own stock as acquisition currency, and access capital markets through the sale of equity securities, mutual insurers are limited to expanding their capital base by generating and retaining earnings. The ability for mutuals to convert to joint-stock organisations is important, however, because it still offers an alternative option to raising additional capital, other than through retained earnings or subordinated debt offerings. This option takes on additional importance if a mutual institution encounters prolonged financial problems such as is evident in the ongoing EL saga. Unlike most private companies, converting mutual institutions have a significant history of publicly available accounting and performance information.

The homogeneous nature of the savings and insurance industry reduces some of the uncertainty and ambiguity in appraising the value of converting institutions, relative to listed comparables. The owners of private companies generally seek to set the initial offering price as high as possible in selling part of their firms to the public, so as to maximise their own profits. This last incentive is missing in a mutual conversion agenda because they have no sellers, only buyers. According to Murray, ${ }^{40}$ financial distress resulting from increasing economic pressures has been the basic motivation for conversion from 
a reciprocal or mutual form of organisation to the stock form. Becoming a stock company enables a firm to expand into multi-line business, form a holding company or be more actively competitive in the market for corporate control. Policyholders benefit from full financial disclosure and equitable compensation in the reorganisation process.

However, there are also several clear arguments against the mutuality principal that also need to be considered. The foremost of these revolve around access to capital markets, more liberal regulatory regimes in respect to diversification and financial service provision, and the discipline imposed by the market for corporate control. Access to capital markets provides opportunities to grow inorganically by acquisition, while at the same time imposing the threat of takeover upon a previously immune institution. Crucially the demutualisation process also aids the hiring and retention of management talent as well as providing incentives for employees through the provision of equity-related compensation packages. The academic literature on ownership and control, stimulated by the work of Jensen and Meckling, ${ }^{41}$ also suggests that an absence of mechanisms of corporate control may lead to unfavourable managerial discretion as suggested by Mayers and Smith. ${ }^{42}$

Hence, managers of mutuals may display a lack of diligence in the management of their corporations, which may be reflected in lower returns, risk aversion and greater expense ratios. Genetay $^{26}$ tests the managerial discretion hypothesis directly through a study covering the period 1988-1992 examining a sample of 41 UK life offices, including 14 mutuals. The author finds that higher levels of risk-aversion characterise the mutual sector, supported by significantly lower average returns on total assets and correspondingly lower volatility of such returns. Importantly however, expense ratios for mutual life offices were not significantly different from those of their proprietary counterparts over the period.

Mutuals that have a modest capital base are inherently vulnerable to unexpected costs arising through unforeseen circumstances. This is a paramount consideration, as the minimum payment guarantees popularised in the 1970s have had to be sustained in the light of falling interest rates and recent legal rulings. Conversely, mutual societies with strong balance sheets and large capital bases are attractive pro-conversion targets for carpet-baggers. This has led to the virtual extinction of mutual societies, as the pro-conversion lobby has preyed upon the strong mutuals, while the weak are themselves vulnerable to capitalisation requirements. This has been accelerated by the spate of recent mergers across the financial services industry, driven by the very market forces that appear to corroborate the need for recapitalisation over the entire assurance sector. The earlier study by McNamara and Rhee ${ }^{43}$ examined the pre- versus post-demutualisation performance of a sample of friendly societies that converted between 1902 and 1986. They showed that demutualisation did not have a significant effect on premium income, the mix of cash value versus non-cash value policies, lapse rates or operating expenses. However, following demutualisation, capitalisation and management turnover increased and the percentage of participating insurance decreased.

The results supported the hypothesis that efficiency rather than expropriation is the motivation and the result of demutualisation. Given the severely 
attenuated system of ownership claims in a financial mutual, it has been predicted that this form will exhibit strong behavioural differences from the stock sector. It is surprising that despite the important corporate governance role accorded to mergers in the corporate literature, the merger process among financial mutuals has been almost totally ignored. Thompson ${ }^{44}$ presents an empirical investigation of the merger process among mutuals via an examination of the targets' characteristics, using a pooled cross section/time series sample of UK building societies between 1981 and 1993. Little support is found for the 'natural selection' view of mutual acquisitions, but the importance of the regulatory process is revealed along with similarities to the merger process in joint-stock firms.

One obstacle to demutualisation, and an obvious but often overlooked expense, is that with hundreds of thousands of newly created shareholders to report to, it can be extremely expensive just to send out the obligatory annual report and accounts. Additionally, in preparation for the necessary mandatory filings, companies typically bring in outside corporate lawyers, accountants, investment bankers as well as actuaries to determine the annual performance in line with Company Act requirements. In the large life insurance companies, the costs amass even faster, as the allocation of equity for lifetime policies is a far more actuarially intensive exercise. This is clearly a major distraction to a company looking to focus on its customers.

As well as the many millions of pounds expended to demutualise, there is also the potential cost of litigation to consider in an insurance company's approach to allocating any surplus.

Recent test cases have allowed increased distribution of orphan assets between policyholders and shareholders in the case of the acquisition of mutual life companies and in the case of recent takeovers. Originally, an informal rule based on Treasury guidelines operated, whereby Life Company orphan assets could be distributed 90 per cent to policyholders and 10 per cent to shareholders. The British subsidiary of AXA, the French insurer, applied to the High Court to seek approval for a controversial plan to reorganise its f1.7bn inherited estate. The Consumers Association (CA) commissioned analysis by actuaries at KPMG that showed policyholders would benefit from only 31 per cent $(£ 525 \mathrm{~m})$ of the orphan assets under the arrangement. The CA claimed this was unfair, despite approval of the scheme by 78 per cent of the company's 660,000 with-profits policyholders, as this was much lower than the 90 per cent figure suggested within Treasury guidelines. The landmark High Court defeat represented a clarification of industry practice regarding orphan assets, as reviewed by Bolger and Targett. ${ }^{45}$

Against such a background, it is likely that every remaining mutual life insurance company will come under sustained pressure to float. National Mutual is reviewing its status, and in September 2000, Scottish Provident was sold to Abbey National for \&1.8bn. Companies that could feasibly demutualise include SL, Royal London (which will have assets under management of around $\delta^{2} 2 \mathrm{bn}$ after its recent acquisition of United Assurance) and the Co-operative Insurance Services (CIS). Financial strength, as measured by free asset ratio (assets in excess of liabilities to policyholders) is an increasingly important marketing tool for independent financial advisors. It also dominates flexibility in the investment approach as long-term liabilities cause the 
adoption of more conservative investment strategies, lowering potential returns, as at the now closed EL fund. The circumstances surrounding this debacle are considered next.

\section{Equitable Life: A resumé of the Guaranteed Annuity Rate controversy}

EL, founded 239 years ago and inventor of the life assurance industry, was put up for sale in July $2000^{46}$ and closed its doors to new business in December of the same year. This heralded the end of an era in mutual life assurance after the company lost its long-running legal battle to reduce bonus payments to holders of guaranteed annuity rate (GAR) policies. Instead, the House of Lords decided other policyholders should make good these guarantees and have their own funds concomitantly reduced. The disastrous set of circumstances that ultimately lost EL's independence had been planted several decades ago, in 1956 when insurers were first allowed to sell pensions to the self-employed. Between 1957 and 1988, EL sold more than 100,000 pension policies offering guaranteed minimum annuity rates, at far below the prevailing long-term interest rates then available. ${ }^{47}$ The real problem only started to emerge in 1993 when annuity rates began to fall significantly and the guaranteed annuity rates, that had previously been considered a minimum, came to become a material issue. Annuity rates had declined because long-term interest rates fell, fuelling rising share prices and causing policyholders' assets to soar. Thus the guarantees written in an earlier epoch were effectively giving policyholders a double take. Conversely, policyholders without guarantees were gaining from rising share prices but crucially losing retirement income from the corresponding collapse in annuity rates. In trying to square the circle of client interests, EL fell back on the industry's right to vary terminal bonuses. In 1993 a decision had to be taken on how to deal with these guaranteed policies, and so EL introduced a differential rate of final bonus; one rate of final bonus for guaranteed annuity policies, and a higher rate for those who elected to take accrued benefits in cash.

Although this policy was introduced in 1993, it was not challenged until 1998, when a dispute arose, led by Stuart Bayliss, a specialist in the retirement annuity sector, and the issue made the headlines. An action group formed from the professional membership challenged this principle, and it became clear that a legal case would be mounted in relation to one specific policyholder. EL reviewed the situation and concluded that it was justified in its earlier actions, as policyholders that tried to exercise their guarantee would have automatically received less cash in the first place with which to buy the corresponding annuity, had a less generous distribution policy been implemented. The company maintained that its approach ensured that all policyholders received approximately the same final pension outcome, irrespective of whether their individual policy contained the specific annuity guarantee or not, which at first view appears to be far more equitable. However, to ensure that the general position was dealt with EL decided instead to institute court action itself.

Treasury guidance arrived in 1998 and backed the stance EL had originally taken. However, the assurer clearly worried regulators at the Treasury, as new solvency rules were about to be introduced by the FSA and in future insurance companies would, for solvency purposes, have to assume that at least 80 per cent of policyholders would choose 
to exercise their guaranteed annuity rate option. Before then insurers had been able to assess the level of take-up individually and to set aside anticipated reserves accordingly — EL anticipated that only 2 per cent of policyholders typically exercised their option, amounting to just a $£ 50 \mathrm{~m}$ contingency. The new solvency requirement meant that EL needed to find an additional f1.5bn and so it decided to engage in 'regulatory arbitrage'. In its Treasury Return for 1998, it put the figure of E1.59bn into its 1998 statutory filing, and bolstered its solvency position by subtly using a series of actuarial and accounting devices.

EL more than doubled its future profit calculation figure from $\mathcal{E} 371 \mathrm{~m}$ in 1997 to $f 850 \mathrm{~m}$ in 1998 and entered into a dubious reinsurance deal with the Irish European Reinsurance Company, a Dublin-based subsidiary of GE Capital. The financial services arm gave EL an extra $\mathcal{C} 700 \mathrm{~m}$ cover for its balance sheet, for a premium of just $\mathcal{1} 150,000$. The result was that publicly EL continued to look financially robust, but privately executives and regulators already knew that the reinsurance deal would not cover the mutual, should its stance on paying guaranteed annuities be overturned in court. EL informed the FSA of the terms of the reinsurance deal but was under no obligation to declare it more publicly. Fortuitously, the High Court initially issued a ringing endorsement from Sir Richard Scott, the Vice-Chancellor, on the way in which EL was dealing with these controversial policies. Unfortunately, EL could not opt out of litigation at this stage, as the Vice-Chancellor not only allowed an appeal, but also said EL should bear the costs. At this stage in proceedings, the legal position worsened quite dramatically. The Appeal Court recorded a 2-1 split decision against EL. ${ }^{48}$ Lord
Woolf, the Master of the Rolls, and Lord Justice Morritt ruled against EL, with only Lord Justice Waller siding with the beleaguered assurer. Finding the judgment 'wholly unsatisfactory' the insurer was forced to take the case onto the Law Lords.

On July 20th, 2000, the House of Lords ruled that EL, the world's oldest mutual life assurer, ${ }^{49}$ had acted unlawfully in reducing terminal bonuses to 90,000 policyholders. EL imposed the reductions because falling interest rates caused its guaranteed annuity policies to exceed available market annuity rates. In his summation, Lord Steyn considered that the provision of guaranteed annuity rates, originally conceived as a marketing ploy, was in fact a vital selling point; even if no one at the time thought this option would ever be exercised.

EL's guaranteed annuity rates ranged from 9.32 per cent for women aged 60 to 13.8 per cent for men aged 70 , versus just 7.3 per cent and 10.8 per cent respectively in the open market. EL was therefore left with a $\mathcal{E} 1.5 \mathrm{bn}$ hole and within hours it was put up for sale. In 1992, SL had originally proposed a merger with EL, but the grand old assurer was fiercely independent and rebuffed the invitation. Without a fresh injection of capital, EL faced liquidity problems as the structural fall in long-term interest rates over the past decade made it difficult for the investment fund to meet the high returns implicitly guaranteed by the policies written prior to the late 1980s.

Historically the insurer had not set aside any surplus capital for such a contingency, leaving it with little choice but to seek outside financial support. Its history marked the life assurer out as special, as did its philosophy of declaring and distributing in full all investment gains to policyholders throughout the lifetime of their respective policies. The 
culture at EL meant that to hold back benefits from one generation to build up reserves for a future generation, appeared to provide a deliberate cross-subsidy between generations, and was not considered 'equitable'. This altruistic ambition underlined sound commercial logic, since it sustained a virtuous circle. By giving back so much to its policyholders, EL's returns stayed at or near the top of the performance league tables, thereby helping it to win yet more business.

The court of final appeal's judgment effectively maintained that the mutual's attempt to cut bonus rates on certain pensions was ultra vires and put it in breach of contract with it customers, paving the way for the headline claim. The mutual's initial error was in originating these policies. This was unwittingly compounded by the open-ended nature of the implied guarantee. The guarantee generously applied whenever a pensioner made an election to retire between the ages of 60 and 75 , while other companies fortuitously guaranteed policies only on a particular retirement date.

Moreover, EL was extremely successful in selling these policies to a client base comprising a majority of the professional classes. Furthermore, it traditionally ran a full distribution policy, thereby denying it a large orphan estate or pool of free assets to cushion the blow. In the absence of any of these single contributory factors, the outcome could have been very different. EL had always run on the tightest of capital bases - at the end of 1999 it stood at just over 2.6 times the minimum solvency margin set by the insurance industry regulators. By way of comparison at SL, another notable mutual provider, the minimum solvency margin coverage was over six times. The performance of the EL pension fund was also enhanced by not paying dividends to shareholders or commission to IFAs. EL practically invented the concept of mutual life assurance and with-profits investment, and its expense position was extremely strong with an expense ratio of just 4.9 per cent compared with 9 per cent for its nearest competitor. The controversial judgment pushed EL's coverage below 1.5 times, leaving the board with no choice but to sell out. EL had to meet its guaranteed annuity payments in full, through a transfer of value from other with-profits policyholders, having given the rights to customers on retirement to buy annuities from the company at the guaranteed rates. That option has proved very expensive because of plunging annuity rates in the open market.

Absolute guarantees have historically led life assurers into trouble, and with hindsight, it was folly in this particular case. The blame must lie with operational management of the time, due perhaps to a lack of actuarial sophistication and foresight, despite the fact that every other life assurer followed suit. EL should have set aside reserves for just such a contingency; but that went against the grain of the mutual's laudable philosophy that all investment returns should be distributed in full to policyholders, leaving no surplus or 'orphan' estate.

Ironically, other less scrupulous life assurers were better placed to make good on these onerous guarantees, although the cost to the entire industry is estimated at up to $\mathcal{K}_{10 \mathrm{bn}}$. EL has 600,000 high-value customers, with a strong position among the professionals and must now meet guaranteed annuity payments through a transfer of value from other with-profits policyholders, which resulted in a loss of value for clients. EL's fate provides further evidence of the shortcomings of the mutual structure, according to Plender. ${ }^{50}$ 
Fortunately for EL members the shortfall is to be filled by Halifax PLC, in combination with the agreed settlement with GAR holders, considered further in Appendix 2. EL was still attractive to potential bidders because of its large pool of funds under management, balance sheet depth and the additional capacity to leverage activities off an expanded asset base, due to synergies from the integration of distribution channels and joint sales forces. This is increasingly important, as pension funds need to increase returns to scale by further equity investment, within the confines of prudence inculcated by a stricter regulatory regime.

\section{Conclusions}

Mutuality has served policyholders well for over two centuries, and with proper management and creative attention to competitive challenges, it could continue to prosper. However, three of the UK's largest remaining mutuals, Friends Provident, Scottish Provident and Scottish Life have ended nearly 200 years of member-ownership by being acquired or converting to public companies in 2001, triggering windfalls worth $\mathcal{L}^{5}$.2bn. This latest round of demutualisations may represent a watershed for mutuality in the UK, leaving SL increasingly isolated as the country's largest mutual life assurer, with $\mathcal{E} 80 \mathrm{bn}$ of assets under management. The best form of government may be a benevolent dictatorship, but democracy is seen as a safe alternative, in that at least it allows for the deposition of a bad dictator. Owning shares fulfils a similar function in capital markets as it allows bad management to be removed. If mutuals are to thrive, they will need to be at least as efficient as shareholder-owned companies, accountable to their members, and able to demonstrate clearly that benign mutuality has tangible financial advantages over shareholder democracy. For the non-mutuals, 10 per cent of the annual excess arising from the life funds goes to pay dividends to shareholders. Mutual life assurers can hand this excess out directly to policyholders. However, the epoch in which mutuality was first conceived, that of the self-help movement of the 19th century has passed, and instead of uniting to protect themselves in the financial services jungle, individuals now clamour for a government regulator to defend them. Mutuals can therefore no longer operate in their own little world, and an increasingly regulated environment presents a whole new set of problems for them. The overwhelming need for life insurers to increase capital reserves due to changing pension regulations and recent legal challenges has forced much radical thinking.

Increased competition from commercial banks and other domestic financing sources, coupled with volatile interest rates periods have led to additional problems. Indeed, the very regulation originally intended to protect mutuals from competition has proved a handicap in obtaining flexibility needed to thrive in modern financial markets. The lesson of the past decade is that the structure in its present form has flaws, evidenced by the demutualisation wave of the late 1990s, and more recently by the events at EL. The EL episode clearly originated from an earlier managerial failure in not recognising the need to make any contingencies against the vagaries of uncertain litigious proceedings. This error was compounded by a severe case of 'regulatory failure' due in part to the protracted handover from the Treasury to the newly formed FSA, which stalled the alarm bells from ringing. Finally, the débâcle highlighted a structural weakness in the mutual form, 
as the lack of access to capital markets meant certain failure in an absence of any outside funding opportunities. While the image of mutuals might have been one of cosy cooperation for common benefit, more recently the stark economic reality has involved very serious conflicts of interest, as unpalatable as any served up on the stock market. Irrespective of any sentimental attachment to the broader principles of mutual ownership it is clear that mutual financial institutions have to continue to evolve if they are to thrive in the $21 \mathrm{st}$ century or otherwise face an unpalatable Darwinian fate.

\section{Appendix 1: Mutual holding structure arrangements}

Under a holding structure arrangement, a mutual remains the holding company, but raises capital via a subsidiary, while retaining a majority stake and overall control. The sponsoring mutual can then transfer some insurance business to the subsidiary and write new business through it. Policyholders retain their voting rights, raising capital without giving up control of operations. As shown by the experience of the USA thrift industry, the issuance of subscription rights in mutual holding company reorganisations provided a crucial means of balancing the business objectives of a mutual company with the rights and interests of policyholders. This halfway house allows the reorganising insurer to achieve the benefits of minority stock ownership — such as access to capital and greater flexibility to pursue strategic merger and acquisition opportunities - while strengthening the unique customer/owner feature of mutuality. Keating ${ }^{51}$ argues that the question of adopting a mutual insurance holding structure remains a controversial one though. There have been instances where former mutuals have attempted to use the legal process to frustrate members' ownership rights, by separating the ownership and equity components in some US states. The mutual company separates the policyholders' contractual rights, as specified by their policy documents, from their ownership rights to vote for directors and to the company's assets, including any surplus. These latter rights are transferred to a 'mutual insurance holding company', which then creates a public stock holding company, operating the new stock insurance company as one of its subsidiaries.

The facilitating stock holding company can sell up to 49 per cent of its voting shares and 100 per cent of its equity to outside investors. Policyholders are left with 51 per cent or more of the voting rights in a 'mutual' shell company, but they get no equity, and therefore no rights to any market gains made by the new stock.

The executives, meanwhile, are insulated from the disapproval of either the new shareholders (who can own at most 49 per cent of the voting rights in the stock company) or the current policyholders (who do not own stock and are generally ineffective in asserting their voting rights). It therefore puts management in the position to enlarge their companies, to make acquisitions and benefit from performance related perks, but crucially terminates any rights policyholders may have to their companies' surpluses, without any compensation. Generally, policyholders do not buy their policies on the understanding that they may enjoy a share in any surplus, and they receive no compensation when they leave, arguably justifying the move to mutual holding structures. As policyholders make no explicit capital contribution towards membership interests, it can be 
concluded that the current generation is not unique and no more entitled to take capital out of the organisation, leaving none for future policyholders, than any other group would have been, obviating the right to any windfall payments.

\section{Appendix 2: EL compromise arrangement and further litigation}

Between the Lord's ruling and the compromise agreement, EL was acutely vulnerable to a vicious circle. The stock market fell just as premium income more than halved, with the closure to new business, and the number of policyholders retiring and taking benefits concomitantly increased. In March 2001, EL announced it was doubling to 15 per cent exit penalties for investors who cashed in with-profits policies early. With effect from the end of 2001, with-profits pension values were effectively cut by 16 per cent and life policies by 14 per cent. Under the approved compromise agreement, policyholders with valuable guaranteed annuity rates (GARs) voted to surrender them up in return for an average 17.5 per cent rise in pension policy values, less than the implied value of their guarantees, but with an opportunity for reinvestment. The non-GARs policyholders were offered a 2.5 per cent increase, in exchange for giving up the right to sue the life assurer for mis-selling.

EL had almost 60 policies offering guaranteed rates, with the terms varying alongside the interests of respective policyholders. In reaching a compromise, EL had to weigh up the conflicts of interest across a multiplicity of policyholders to cap exposure to GARs. The actuarial calculation was to determine the value of an annuity paid at a guaranteed rate in excess of available market rates. The compromise had to be attractive enough on the one hand to persuade one set of policyholders to give up their guarantees, while on the other hand not penalising non-guaranteed policyholders too much. Equitable effectively offered the GAR holders a refund on the 2001 with-profit pension cuts, and non-GAR holders a dividend based on the ${ }^{2} 250 \mathrm{~m}$ the Halifax contracted to pay should a compromise be agreed by March 1st, 2002. EL appointed an independent actuary at Hymans Robertson to scrutinise the compromise deal, providing a detailed report to all policyholders on the actuarial reasonableness and fairness of the terms, along with the benefits among classes of policyholders. In view of the controversial $^{52}$ compromise future annual bonuses were anticipated to accrue at a new lower rate of 6 per cent annually, based on the reduced fund values, as compared with previous headline bonus rates of around 8 per cent. Although no annual bonuses were proposed for the first six months of 2002 exit penalties were halved to 7.5 per cent. In February 2002 the High Court sanctioned the compromise proposal after members had overwhelmingly supported it.

Outside of the adopted GAR settlement, EL denies any generic mis-selling liability, but commissioned an independent review by consulting actuaries B\&W Deloitte to investigate whether any losses suffered by former policyholders who may have been mis-sold, were due to GAR issues, rather than a fall in the stock market. The former policyholders to be considered under the review are non-GARs who took their money out before the compromise deal came into effect. In such cases, there may be claims that policies were mis-sold at the time, since the GAR liabilities were either withheld or materially understated. A f270m contingency has already been set aside to cover non-GAR compensation claims, 
although part of this was used to fund the 2.5 per cent uplift provided for non-GAR policyholders under the compromise arrangement. Remaining policyholders have already surrendered any right to compensation attributable to mis-selling, under the terms of the adopted compromise deal.

\section{References}

1 Howcroft, B. (1999) 'Mutuality versus Public Company - the Debate in Europe and USA', Corporate Governance Scholarly Research, Vol. 7, No. 2, pp. 167-177.

2 Orphan assets are assets built up in insurers' life funds greater than the amount needed to satisfy policyholders' 'reasonable expectations', as investment returns within with-profits funds are apportioned each year between bonuses to with-profits policyholders and reserves to cushion the fund against unexpected shocks. However, there are no clear legal or financial formulae defining 'reasonable' leaving scope for recent legal challenges,

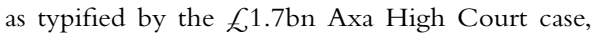
brought by the Consumers Association and briefly reviewed in our section on the demutualisation debate.

3 Fabian, D. T. (1985) 'Demutualization - Will It Become the Fashion?', Benefits and Compensation International, Vol. 14, No. 12, pp. 21-25.

4 A carpet-bagger was originally an American derogatory term applied by the people of the Southern states to people from the Northern states, who had travelled to the South during the 'Reconstruction' period following the American Civil War (1861-1865). The term was coined to suggest that 'Northerners' could pack everything they possessed into a carpet-bag, or simple satchel made of carpet. Indeed many carpet-baggers were opportunists, seeking to exploit the political unrest and financial problems of the South. Contemporarily speaking, the term carpet-bagger refers to roving financial opportunists, often of modest means, who spot investment opportunities and aim to benefit from a set of circumstances to which they are not ordinarily entitled. In recent years, the best opportunities for carpet-baggers have come from opening membership accounts at building societies for as little as $£ 1$, to qualify for windfalls running into thousands of pounds from the process of conversion and takeover. This paper refers to the recent influx of such transitory 'token' members as carpet-baggers, who took advantage of these nugatory deposit criteria, often to instigate or accelerate the trend towards wholesale demutualisation.

5 Shay, R. P. (1992) 'Mutual Savings Institutions', in Eatwell, J., Milgrom, M. and Newman, P. 'The
New Palgrave Dictionary of Money \& Finance', Vol. 2, Macmillan, London, pp. 832-834.

6 Anonymous (1994) 'Mutual Benefit', Absolute Beginners, Investors Chronicle, Vol. 110, No. 1396, 21st-27th October, p. 41.

7 Stahl, D. (1995) 'Promoting Mutuality', America's Community Banker, Vol. 4, No. 11, November, p. 9.

8 Anonymous (1994) 'Mutual Benefits', Centre for the Study of Financial Innovation, The Banker, Vol. 144, No. 824, October, p. 16.

9 Anonymous (2001) 'Mutual Thoughts', No Free Lunch, Investors Chronicle, Vol. 136, No. 1731, 11th-17th May, p. 106.

10 Anonymous (1994) 'More about Mutuality', Absolute Beginners, Investors Chronicle, Vol. 110, No. 1397, 28th October-3rd November, p. 54.

11 Cook, J., Deakin, S. and Hughes, A. (2001) 'The Governance of Mutuality: Building Societies, Property Rights and Corporate Governance', ESRC Centre for Business Research, Cambridge, pp. 1-87.

12 Martin, P. (1999) 'Our Mutual Demise: The Rush to Demutualise has come about largely because of the Falling Cost of Capital', Financial Times, 29th June, p. 18.

13 Green, M. R. and Johnson, R. E. (1980) 'Stocks vs. Mutuals: Who Controls?', Journal of Risk and Insurance, Vol. 47, No. 1, pp. 165-174.

14 London, S. (2001) 'Endangered Species', FT Money Section: Personal Finance, Financial Times, Weekend Edition, 3rd-4th February, p. 6.

15 Mayers, D. and Smith, C. W. (1986) 'Ownership Structure and Control: The Mutualization of Stock Life Insurance Companies', Journal of Financial Economics, Vol. 16, No. 1, May, pp. 73-98.

16 Mackintosh, J. (2001) 'Forces Regroup for the Bigger Battles to Come', FT Survey: Mutuality, Financial Times, 4th May, p. 3.

17 Bolger, A. (2001) 'Danger of Too Much or Too Little Capital', FT Survey: Mutuality, Financial Times, 4th May, p. 3.

18 Croft, J. (2001) 'Royal London looks at Unlocking Orphan Estate', Financial Times, 19th March, p. 4.

19 Evans, J. (1998) 'Carpetbagging: Windfalls All Round for Carpetbaggers', Investors Chronicle, Vol. 123, No. 1569, 13th-19th March, pp. 19-20.

20 Brown-Humes, C. (1999) 'A Marriage Of Convenience', Financial Times, 24th June, p. 19.

21 Cole, R. A. and Mehran, H. (1998) 'The Effect of changes in Ownership Structure on Performance: Evidence from the Thrift Industry', Journal of Financial Economics, Vol. 50, No. 3, pp. 291-317.

22 The accountants KPMG's survey of building societies showed the net interest intermediation margin was 0.5 per cent lower than for comparable investor-owned organisations.

23 Anonymous (1999) 'Mutually Assured Destruction?', Finance and Economics, The Economist, Vol. 351, No. 8117, 1st-7th May, pp.109-110.

24 Clarke, T. (1998) 'In Defence of Mutuality', Corporate Governance: A European Review, Vol. 7, No. 2, pp. 97-102.

25 The author is grateful to Dr David Starkie for 
highlighting the following issue: It is not whether or not mutuality should continue to exist per se, as at one level it may not matter; since if one firm is the superior financial species, then evolution ought to prevail. However, what is more concerning from a competition perspective regarding the potential extinction of the mutual sector is the financial impact on the marketplace of a wholesale withdrawal of not-for-profit competition. This is an important question, as the existence of a strong mutual sector may play a crucial part in stimulating economic and financial development associated with financial diversity. The dynamics of competition are expressed through the generation of ideas, producing a variety of economic outcomes. From one perspective, it could be argued that the sum of the whole is greater than its individial parts. Perhaps there is an argument somewhere in the middle based on 'synergy' between the two camps, whereby one acts to stimulate and simultaneously provide checks and balances on the activities of the other; a co-existence or symbiosis hypothesis, generating overall improved social welfare, rather than pure domination and extinction. This is almost a counter-Darwinist proposal, based on the retention of variety in the financial 'gene pool', to countervail the real risk of profound economic and efficiency issues related to domination.

26 Genetay, N. (1999) 'Ownership Structure and Performance in UK Life Offices', European Management Journal, Vol. 17, No. 1, pp. 107-115.

27 Stahl, D. (1995) 'Promoting Mutuality', America's Community Banker, Vol. 4, No. 11, p. 9.

28 Valnek, T. (1999) 'The Comparative Performance of Mutual Building Societies and Stock Retail Banks', Journal of Banking and Finance, Vol. 23, No. 6, pp. 925-938.

29 Barker, A., Dunham, W. and Kelly, G. (1990) 'Acquisitions of Insurers by Demutualisation', International Financial Law Review, Vol. 9, No. 10, pp. 20-24.

30 Sanders, A. J. (2000) 'Mutual Holding Structures: the Case of NPI', Institute of Actuaries.

31 Anonymous (1999) 'Trouble's Still Knocking at Mutuality's Door', Personal Finance, Investors Chronicle, Vol. 128, No. 1631, 28th May-3rd June, pp. 32-33.

32 Bolger, A. (2000) 'Milestone in March away from Mutuality', Financial Times, 9th December.

33 Guthrie, J. (2001) 'Methods to Shake the Methodists', FT Survey: Mutuality, Financial Times, 4th May, p. 2.

34 Voyle, S. (2001) 'Shopping Around for Solutions', FT Survey: Mutuality, Financial Times, 4th May, p. 3.

35 A friendly (or provident) society is an association, typically a pensions body, to which members subscribe small amounts of money over long periods to a collective fund. Friendly societies have existed for over 150 years, with currently around 350 registered in the UK, representing the combined interests of some $8 \mathrm{~m}$ members and customers.
Friendly Societies are registered under the Friendly Societies Act 1974 as voluntary, mutual organisations whose main purpose is in assisting members financially during sickness, unemployment or retirement, and the provision of life assurance. Members of the early friendly societies typically met in pubs and inns, the social aspect being an important part of the gatherings. At this time, the bleak prospect faced by the mass poor was the workhouse, making the advantages of joining an organised friendly society particularly attractive. By 1875 the Friendly Societies Act called for proper auditing and registration. Societies became more efficient at managing funds and friendly society membership soared peaking in 1893 when approximately 27,000 societies had registered. Under the 1911 National Insurance Act, to provide health care, sickness and maternity benefits, friendly and 'approved' societies were used to administer scheme assets. This continued until 1945 when the creation of the Ministry of National Insurance took over.

36 Gilmore, R. (1998) 'Mutuality for the Twenty-First Century', Center for the Study of Financial Innovation, Report No. 33.

37 Brown-Humes, C. (1999) 'Carpetbaggers found the Door left Open: Building Society Demutualisations', Financial Times, 27th April, p. 24.

38 Fama, E. F. and Jensen, M. C. (1983) 'Separation of Ownership and Control', Journal of Law and Economics, Vol. 26, pp. 301-325.

39 Warner, A. (1997) 'Faith of the Converted', The Banker, Vol. 147, No. 856, June, pp. 24-25.

40 Murray, G. E. (1985) 'Demutualization of Insurance Companies - Advantages and Disadvantages', Journal of the American Society of CLU, Vol. 39, No. 1, January, pp. 52-54.

41 Jensen, M. C. and Meckling, W. H. (1976) 'Theory of the Firm: Managerial Behaviour, Agency Costs and Ownership Structure', Journal of Financial Economics, Vol. 3, No. 4, pp. 305-360.

42 Mayers, D. and Smith, C. W. (1994) 'Managerial Discretion, Regulation, and Stock Insurer Ownership Structure', Journal of Risk and Insurance, Vol. 61, No. 4, pp. 638-655.

43 McNamara, M. J. and Rhee, S. G. (1992) 'Ownership Structure and Performance: The Demutualization of Life Insurers', Journal of Risk and Insurance, Vol. 59, No. 2, pp. 221-238.

44 Thompson, S. (1997) 'Takeover Activity Among Financial Mutuals: An Analysis of Target Characteristics', Journal of Banking and Finance, Vol. 21, No. 1, pp. 37-53.

45 Bolger, A. and Targett, S. (2000) 'AXA Defeats High Court Challenge to Plans for $£ 1.7 \mathrm{bn}$ “Orphan” Assets', Financial Times, 22nd December, p. 1.

46 Eaglesham, J., Felsted, A., Pretzlik, C. and Saigol, L. (2000) 'Equitable Life put on the Market', Financial Times, 21st July, pp. 1.

47 Bolger, A. and Targett, S. (2001) 'Fatal Flaw that led to Cracks in a Once Solid City Institution', Financial Times, 15th February. 
48 Equitable Life Assurance Society v. Hyman [2000] 2 W.L.R. 798

49 Founded in 1762.

50 Plender, J. (2000) 'Equitable's Fatal Flaws', Comment \& Analysis, Financial Times, 15th December.

51 Keating, P. (1998) 'Whose Company is it Anyway?', Money, Vol. 27, No. 10, pp. 170-174.

52 Blake, D. (2002) 'An unfair compromise', Personal View, Financial Times, 28th January.

\section{Addendum}

Comments on 'Investigating the benefits of Mutuality: Mutual versus proprietary annuity provision' by Richard Lewin and Stephen Satchell, published in the Journal of Pensions Management, Volume 7, Number 1, September 2001.

The authors were particularly grateful for the following actuarial comments received from Standard Life, under the auspices of David Hare, chairman of the research group of the Faculty of Actuaries, and charged with arranging the February 2002 Sessional Meeting on Corporate Structure.

First, let me say that we were grateful for the opportunity to offer our views on this paper. Our impression is that the paper has covered the key areas and reasons for mutual companies providing higher average annuity rates than proprietary ones. If we may, we would like to offer the following additional comments on the arguments proposed.

Perhaps the most obvious point is that apparently little attention is paid to the dilemma which mutuals can find themselves in, concerning the pricing of non-profit products. In theory, most (if not all) UK mutual assurance companies are being run for the benefit of with-profit policyholders both present and future. This begs the question as to what extent the management is therefore free to charge less than the going rate for non-profit products before the with-profits policyholders then complain that their money is being given away. Of course, it could be argued that mutuals can take a longer-term view and that their cost of capital may be less than that for PLCs and that this could influence pricing policy. In addition, we would like to claim that mutuals, without the inherent conflict between shareholders and policyholders, are well placed to be more policyholder focused, than other types of organisations and that this is not limited solely to with-profits policies. Thus, in seeking to compare mutuals with PLCs, annuity pricing would not be the obvious place to start from our point of view (important though annuities are to the population!).

It is worth noting that this UK issue does not necessarily affect all mutuals internationally. For example, we believe that Vanguard, the USA mutual fund company, prices all its products on a 'mutual basis'.

The statement on p74 that mutuals could have been paying out more than they could afford in the 1990s needs clarification. This could be regarded as simplistic as it ignores the importance of underlying investment mix, for example. The relationship between payouts and affordability is extremely complex. One firm of consultants, Tillinghast, has done a lot of work in this field and their findings appear to suggest that overpayment (with respect to asset share) is more common towards the bottom of performance table rather than the top.

Going through the paper there are some other particular points, which caught our attention:

- p74 Direct Line is owned by the Royal Bank of Scotland and not by HSBC

- p75 There have been other transactions involving a mutual acquiring another company, namely, Royal London's acquisition of United Assurance (a PLC) and, latterly, Scottish Life (another 
mutual, but demutualising as part of the process).

- p75 We are not sure we agree with the first sentence of paragraph 2: in particular, it is not appropriate, in our view, to talk of 'giving back' long-term capital to one particular generation of policyholders who may or may not have contributed to it.

- p75 The reference to Appendix 1 should have been to Appendix 2 .

- p76 It is too simple to say that gilts back annuities. Aside from supply issues which have dogged the market for several years now, it would be virtually impossible to price annuities competitively without at least some exposure to corporate bonds and other higher yielding fixed interest investments (although, of course, the resulting higher risks need to be carefully considered and appropriate provision made in respect of them).

- p77 we presume the word 'morbidity' on line 2 should have been 'mortality'.

- p77 The discussion at the top of the page, concerning offsetting cashflows, is valid, but we would not call that a 'hedge' in the 'future protection' sense of the word. In fact, the 'natural Hedge' is more to do with mortality risk than short-term cashflow management (albeit, the differing rates of mortality improvement currently being seen at different ages do offset this, at least to some extent).

- p77 Without wishing to be precious, only one tranche of Futureperfect (Standard Life) was sold at 6.49 per cent, the second one - the cap for the first tranche was 6.25 per cent and for the third, 6.59 per cent.

- p78 No reference is made to the CMI (Continuous Mortality Investigation) Bureau of the Faculty and Institute of Actuaries.
- p83 Likewise the reference to Appendix 2 should have been to Appendix 1.

The reasons put forward for the recent wave of demutualisations need to include one other very obvious point. The Conclusion section is not entirely correct in implying that the mutuals and capital were widely discussed in the mid to late 80 s, or much written about regarding the difficulties that small to medium size mutuals were facing and would continue to face. Yes, equity growth helped in some cases (but not all - a fact also not highlighted in the paper and which was in our view a key element in the 'demise' of at least two mutual organisations), as the paper mentions. However, there could be more appreciation of the issues which those within the industry would put forward since the reasons for the restructuring we have seen, namely banks' distribution and profit diversification strategies (accounting treatment is regarded by some as something of a side show, despite the inclusion of Appendix 2), constraints on capital (as a result of strong new business growth and/or the increasing effect of guarantees etc), and market distribution dynamics (as a result of the Financial Services Act 1986 and/or the advent of Stakeholder pensions) to name but three.

Finally, we also note that the paper quotes the purchase price of Scottish Widows as 67.3 bn in Appendix 2. The authors are presumably clear about the difference between headline totals and what actually changed hands, as this is an important distinction.

Once again, we would stress how much we welcome the fact that academic research is continuing to be conducted into the role of mutuals and are delighted for the opportunity of corresponding with the authors. 